\title{
Hydrogen generation through cuprous chloride-hydrochloric acid electrolysis
}

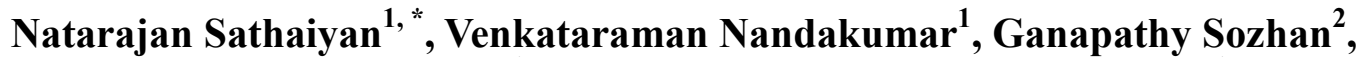 \\ Jegan Gandhibha Packiaraj ${ }^{1}$, Elumalai Thambuswamy Devakumar ${ }^{1}$, Damaraju Parvatalu ${ }^{3}$, \\ Anil Bhardwaj ${ }^{3}$, Bantwal Narayana Prabhu ${ }^{3}$
}

${ }^{1}$ Electro Hydro Metallurgy Division, CSIR-Central Electro-Chemical Research Institute, Karaikudi, India

${ }^{2}$ Electro Inorganic Chemicals Division, CSIR-Central Electro-Chemical Research Institute, Karaikudi, India

${ }^{3}$ ONGC Energy Centre, IEOT, Panvel, Navi Mumbai, India

Email address:

enes@rediffmail.com (N. Sathaiyan)

\section{To cite this article:}

Natarajan Sathaiyan, Venkataraman Nandakumar, Ganapathy Sozhan, Jegan Gandhibha Packiaraj, Elumalai Thambuswamy Devakumar, Damaraju Parvatalu, Anil Bhardwaj, Bantwal Narayana Prabhu. Hydrogen Generation through Cuprous Chloride-Hydrochloric Acid Electrolysis. International Journal of Energy and Power Engineering. Vol. 4, No. 1, 2015, pp. 15-22. doi: 10.11648/j.ijepe.20150401.13

\begin{abstract}
Due to fast industrialization the consumption as well as the cost of fossil fuels like petrol, diesel etc in the world is rising enormously leading to the generation of greenhouse gases like carbon monoxide, carbon dioxide etc besides decreasing the availability of the above fuels. The emission of these greenhouse gases rises the globe's temperature leading the earth to face many dangerous complications. In order to save the earth from effect of rise of temperature and also to have an ecofriendly alternate energy fuel especially for the transport sector, attention is being focused on the generation of hydrogen gas which meets the above situations. During the combustion of hydrogen gas it emits only the beneficial water vapour to the atmosphere. In this research paper investigation has been carried out through $\mathrm{CuCl}-\mathrm{HCl}$ electrolysis with $1 \mathrm{M} \mathrm{CuCl}$ anolyte and $6 \mathrm{M} \mathrm{HCl}$ catholyte for the generation of hydrogen gas at $70^{\circ} \mathrm{C}$ at normal atmospheric pressure employing a double compartment electrolytic cell having a nafion cation exchange membrane-324. Anode was graphite and cathode was $0.30 \mathrm{mg} \mathrm{cm}^{-2}$ platinum coated graphite. At a current density of $250 \mathrm{~A} \mathrm{~m}^{-2}$ the current efficiency for the oxidation of $\mathrm{CuCl}$ to $\mathrm{CuCl}_{2}$ and the formation of hydrogen gas was nearly $100 \%$ and the rate of hydrogen liberation was found to be $21 \mathrm{~h}^{-1}$. Voltage efficiency and energy consumption values are calculated and are found to be more encouraging since they are more economical with less energy operation. The formed $\mathrm{CuCl}_{2}$ was reduced back to $\mathrm{CuCl}$ anolyte by chemical reduction with copper powder in $6 \mathrm{M} \mathrm{HCl}$ at $70^{\circ} \mathrm{C}$ and the regenerated $\mathrm{CuCl}$ anolyte was again used in the $\mathrm{CuCl}-\mathrm{HCl}$ electrolysis.
\end{abstract}

Keywords: Cuprous Chloride-Hydrochloric Acid, Nafion Cation Exchange Membrane-324, Divided Cell, Graphite, Platinum Coated Graphite, Hydrogen Gas, Cupric Chloride

\section{Introduction}

The climate change is a very big challenge imposed on earth by the man mainly due to fast growing industrialization, automobiles, transport and fast developing electronic era. The outcome of this climate change that is global warming leads to various consequences like water pollution, air pollution, decrease in rice production, health, water scarcity in some area (less rain), copious water in some area (more rain) and so on. Warming of earth has been detected by scientists and they explain that it is due to the emission of green house gases like carbon dioxide, methane, nitrous oxide etc. Scientists have observed more acid content over the surface of sea mainly due to the rain water having more acid levels. All these are primarily due to the over exploitation of usage of fossil fuels like coke, wood, petrol, diesel etc for producing electricity/meeting the fuel demand/energy requirement. Even then the energy demand could not be fully solved due to gradual decrease in their supply/production, increase of their price and also due to economic sanctions imposed on some countries having excess oil due to various political factors.

Due to the above consequences it is paramount necessity to have a substitute with clean renewable energy systems at competitive market costs with fast technological development. Rechargeable batteries store energy for latter 
use can meet the energy demand only to a very little extent. The continuous use of storage batteries may generate solid and chemical wastes after their service life leading to various safe disposal problems. Among the promising energy substitutes the hydrogen gas has many attractive features like its multi functionality, cleanness, zero emission of green house gases only steam emission due to its combustion. Hydrogen is high in energy content as it contains $120.7 \mathrm{KJ} \mathrm{g}^{-1}$

Hydrogen gas can be produced from various sources besides from water which is abundant.

Hydrogen gas production from water by electrolysis is cited in [1,2,3]. Ref [4] furnishes the details of generation of hydrogen from the electrolysis of seawater. Liquid ammonia is another interesting source for the generation of hydrogen by electrolysis [5]. Hydrazine can also be used for the generation of hydrogen gas employing nanocatalysts [6]. Solar energy can be judiciously employed to produce hydrogen gas from water by electrolysis [7]. Biosynthesis route is also reported for producing hydrogen and ethanol from glycerol fermentation [8]. Steam Reforming is another way of producing hydrogen along with carbondioxide capture [9]. Generation of hydrogen gas is also indicated through biocatalysed electrolysis [10].

Eventhough hydrogen can be produced through several routes as cited above these methods have many disdvantages due to the following factors like very expensive/high energy process, no guarantee for the availability of solar energy throughout the year, liberation of unwanted toxic gas like chlorine, conducting electrolysis with costly instruments like potentiostat besides dealing with highly corrosive liquid as electrolyte, involving costly chemicals like nanoparticles, very slow process like fermentation using costly organic chemical, liberation of greenhouse gases like carbon dioxide

via steam reforming etc. But it is observed that hydrogen will not have a major role in India without considerable research on technology innovations and reductions in production cost. In that angle it is felt that hydrogen formation by a novel method other than cited above should satisfy these criteria. Hydrogen formation through the thermochemical cycles is an example for this. Thermochemical cycles combine solely heat sources like steam, nuclear and thermal heat with chemical reactions to split water into hydrogen and oxygen. The word cycle is used since water is split into hydrogen and oxygen while the chemicals employed in these processes are continuously recycled. Eventhough there are many thermochemical cycles available before us like ceriumchlorine [11], iron-chlorine [11], copper-sulphate [11], vanadium-chlorine [12], magnesium-iodine [13] and sulphuriodine [14] the copper-chlorine thermochemical cycle is found to be best since it has a very low operating temperature of less than $550^{\circ} \mathrm{C}$ than other thermochemical cycles.

The optimised copper-chlorine $(\mathrm{Cu}-\mathrm{Cl}$ cycle) is a threestep thermochemical cycle for generating hydrogen gas. The $\mathrm{Cu}-\mathrm{Cl}$ cycle is a hybrid process involving both thermochemical and electrolysis steps. Its maximum operating temperature is about $530^{\circ} \mathrm{C}$. This cycle involves four chemical reactions for the splitting of water whose net reaction is the decomposition of water into hydrogen and oxygen. All other chemicals that are involved are recycled. To attain maximum efficiency, minimum environmental impact and minimum cost of hydrogen generation the $\mathrm{Cu}-\mathrm{Cl}$ cycle can be joined with waste heat available from solar, industry and nuclear plants. The $\mathrm{Cu}-\mathrm{Cl}$ cycle is one of the prominent thermochemical cycles under development within the Generation IV Internal Forum (GIF).

The reactions in the $\mathrm{Cu}-\mathrm{Cl}$ cycle are given below $[15,16]$.

$$
\begin{gathered}
2 \mathrm{CuCl} . \mathrm{nH}_{2} \mathrm{O}(a q)+2 \mathrm{HCl} \cdot \mathrm{mH}_{2} \mathrm{O}(a q) \rightarrow 2 \mathrm{CuCl}_{2} \cdot(\mathrm{n}+\mathrm{m}) \mathrm{H}_{2} \mathrm{O}(a q)+\mathrm{H}_{2}(g) \text { [electrolysis at } 25-80^{\circ} \mathrm{C} \text { ] } \\
\left.2 \mathrm{CuCl}_{2}(s)+\mathrm{H}_{2} \mathrm{O}(g) \rightarrow \mathrm{CuO}(s) \mathrm{CuCl}_{2}+2 \mathrm{HCl}(g) \text { [hydrolysis at } 310-375^{\circ} \mathrm{C}\right] \\
\mathrm{CuOCuCl}_{2}(s) \rightarrow 2 \mathrm{CuCl}(s)+1 / 2 \mathrm{O}_{2}(g)\left[\text { decomposition at } 450-530^{\circ} \mathrm{C}\right]
\end{gathered}
$$

Net reaction is the splitting of water into hydrogen and oxygen gases as shown by the equation given below.

$$
2 \mathrm{H}_{2} \mathrm{O} \rightarrow 2 \mathrm{H}_{2}+\mathrm{O}_{2}
$$

In reference to the reaction (1) the principle of $\mathrm{CuCl}-\mathrm{HCl}$ electrolysis is that cuprous chloride, $\mathrm{CuCl}$ which is dissolved in high concentrated $\mathrm{HCl}$ is employed as anolyte (electrolyte surrounding the anode) while high concentrated $\mathrm{HCl}$ is used as catholyte (electrolyte surrounding the cathode) in an polyethylene made electrolytic divided closed cell employing cation exchange membrane. The $\mathrm{CuCl}$ in $\mathrm{HCl}$ is present as chloride complexes like $\mathrm{CuCl}_{2}{ }^{1-}$ and $\mathrm{CuCl}_{3}{ }^{2-}$ when the $\mathrm{HCl}$ concentration is around $6 \mathrm{M}$. As shown by Eq (1) when the DC current is applied to the cell the cuprous chloride $(\mathrm{CuCl})$ anolyte is oxidized to cupric chloride $\left(\mathrm{CuCl}_{2}\right)$ as given below.

$$
2 \mathrm{CuCl}+2 \mathrm{HCl} \rightarrow 2 \mathrm{CuCl}_{2}+2 \mathrm{H}^{+}+2 \mathrm{e}^{-} \quad \mathrm{E}^{\mathrm{o}}=0.15 \mathrm{~V} \text { vs SHE }
$$

The catholyte $(\mathrm{HCl})$ is reduced to hydrogen gas as indicated below.

$$
2 \mathrm{HCl}+2 \mathrm{e}^{-} \rightarrow \mathrm{H}_{2}+2 \mathrm{Cl}^{-} \mathrm{E}^{\mathrm{o}}=0.00 \mathrm{~V} \text { vs SHE }
$$

This research paper presents the result generated on the formation of hydrogen gas with minimum cell potential from the electrolysis of acidic cuprous chloride-hydrochloric acid system employing a divided electrolytic closed cell having cation exchange membrane using graphite anode and platinum coated graphite cathode under various experimental conditions.

\section{Experimental}

\subsection{Cell for Basic Studies Using Cyclic Voltammetry}

A three electrode glass cell with volume capacity of 150 $\mathrm{ml}$ with Pt foil as working electrode, Pt rod as counter electrode and $\mathrm{Ag}-\mathrm{AgCl}$ as reference electrode was employed 
for undertaking basic studies with Autolab system. All experiments were carried out at room temperature and potentials were measured. Before each cyclic voltammetric (CV) study, the working electrode was polished by fine emery paper followed by cleaning and washing. All electrode potentials other than $\mathrm{CV}$ in this research paper are given in respect of saturated calomel electrode (SCE).

\subsection{Electrolytic Cell for Applied Studies}

Fig 1 depicts the cell set-up for the generation of hydrogen gas with the formation of cupric chloride from the $\mathrm{CuCl}-\mathrm{HCl}$ electrolysis.

A filter press type closed divided cell made up of polypropylene material for high temperature operation was fabricated employing graphite plate anode and platinum coated graphite plate cathode. The electrolytes, anolyte $(\mathrm{CuCl}$ in $6 \mathrm{M}$
$\mathrm{HCl})$ and catholyte $(\mathrm{HCl})$ were circulated in the electrolytic cell through peristaltic pumps at moderate flow rates. The electrolytic solutions taken in the round bottom flasks were heated externally by heating mantles. Nafion cation exchange membrane was used as membrane in the cell. Provisions were made in the cell for measuring the electrode potentials during the electrolysis with saturated calomel electrodeas reference electrode and also having provision for measuring the temperature in each compartment. Tygon tube which can withstand high operating temperature and high acid concentration was used in the cell set-up for the circulation of electrolytes. Cell having about 11 volume capacity with 5A current was fabricated in our lab (CECRI, Karaikudi) and used in the experimental investigations of $\mathrm{CuCl}-\mathrm{HCl}$ electrolysis for the formation of cupric chloride and generation of hydrogen gas with high efficiency and high purity.

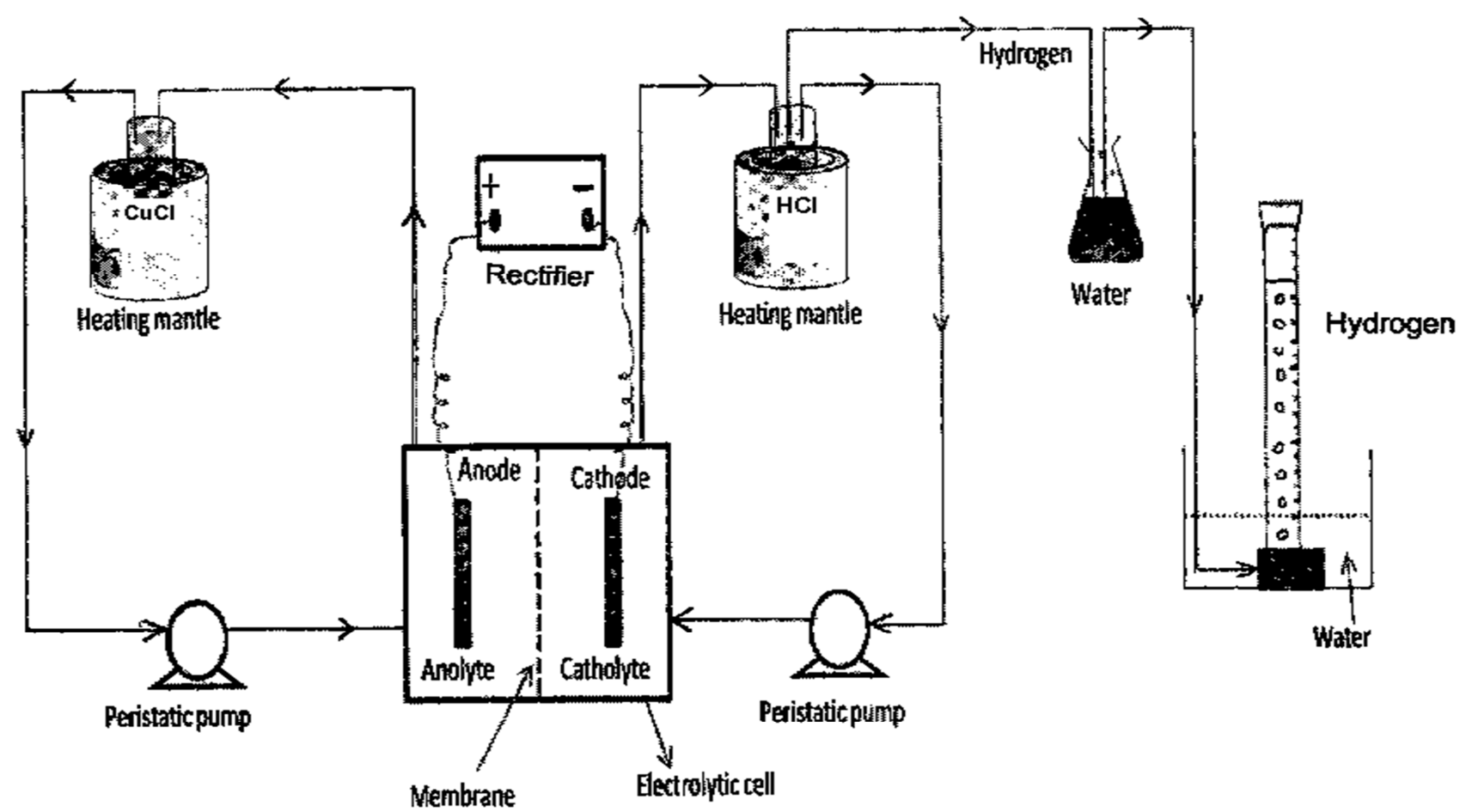

Fig 1. Cell Set-Up for the hydrogen generation through $\mathrm{CuCl}-\mathrm{HCl}$ electrolysis

The galvanostatic experimental studies were conducted in a divided closed double compartment cell capable of holding $400 \mathrm{ml}$ of electrolyte in each compartment separated by nafion cation exchange membrane-324. The cell consisted of PP (polypropylene) frames of size $22 \mathrm{~cm}$ length $\mathrm{x} 15 \mathrm{~cm}$ breadth $\times 1.25 \mathrm{~cm}$ thick for the cell with provision for the inlet and outlet in each compartment which functioned as anolyte and catholyte compartments. Graphite plates of the same size were used as anode and cathode (with Pt coating of $\left.0.1-0.5 \mathrm{mg} \mathrm{cm}^{-2}\right)$. Anolyte $(\mathrm{CuCl}$ in $6 \mathrm{M} \mathrm{HCl}, 1100 \mathrm{ml}$ at 401 $\left.\mathrm{h}^{-1}\right)$ and catholyte $\left(\mathrm{HCl}, 1100 \mathrm{ml}\right.$ at $\left.10 \mathrm{l} \mathrm{h}^{-1}\right)$ were circulated by peristaltic pumps through tygon tubes into the respective compartments from the reservoirs (multi neck round bottom glass flask) of 21 capacity. The electrolyte solutions were heated to the required temperatures $\left(30-85^{\circ} \mathrm{C}\right)$ through heating mantles separately. Electrolysis was conducted for a period of 1-5 $\mathrm{h}$ in the range of current density of 250-1000 A $\mathrm{m}^{-2}$ with a minimum inter electrode gap of $1.5 \mathrm{~cm}$. The liberated hydrogen gas from the cathode chamber is passed through the distilled water kept in a sealed glass conical flask and then the hydrogen gas was allowed to pass through a trough having inverted glass measuring jar to collect the purified hydrogen gas besides measuring the volume of hydrogen gas.

\subsection{Characterization of Graphite Electrodes}

Scanning electron microscopy (SEM) has been used for studying and characterizing the surface morphology of plain graphite cathode, Pt coated graphite cathode before and after electrolysis. 


\section{Results and Discussion}

\subsection{Basic Studies with Cyclic Voltammetry}

The net electrolytic reaction taking place in the $\mathrm{Cu}-\mathrm{Cl}$ electrolysis is

$$
2 \mathrm{CuCl}+2 \mathrm{HCl} \rightarrow 2 \mathrm{CuCl}_{2}+\mathrm{H}_{2}
$$

Basic study was carried out using CV for understanding the reaction mechanisms and also for knowing electrode potentials in the $\mathrm{CuCl}-\mathrm{HCl}$ electrolysis for the generation of hydrogen gas. $\mathrm{CV}$ was carried out with $\mathrm{HCl}$ with the range of $1-11 \mathrm{M}$ for determining the potential for hydrogen liberation in the potential range of $0.00 \mathrm{~V}$ to $-1.00 \mathrm{~V}$ with potential scan of 100 $\mathrm{mV} \mathrm{s}^{-1}$ with Pt wire as working electrode and Pt rod as counter electrode. The potential was found to be less negative from $0.38 \mathrm{~V}$ to $-0.14 \mathrm{~V}$ as the $\mathrm{HCl}$ concentration was increased from $1 \mathrm{M}$ to $11 \mathrm{M}$. In Fig 2 a cathode potential of $-0.18 \mathrm{~V}$ was observed for the hydrogen liberation from $6 \mathrm{M} \mathrm{HCl}$.

This is in conformity with the literature [17] since at this concentration of $6 \mathrm{M} \mathrm{HCl}$ the precipitation of $\mathrm{CuCl}$ is avoided besides having observed less potential for the hydrogen liberation.

The $\mathrm{CV}$ of $\mathrm{CuCl}$ solution is shown in Fig 3. $\mathrm{CuCl}$ solution with $0.08 \mathrm{M}$ strength was prepared in $6 \mathrm{M} \mathrm{HCl}$ for the potential measurements in the potential range of $0.00 \mathrm{~V}$ to $+0.75 \mathrm{~V}$ having a scan rate of $50 \mathrm{mV} \mathrm{s}^{-1}$.

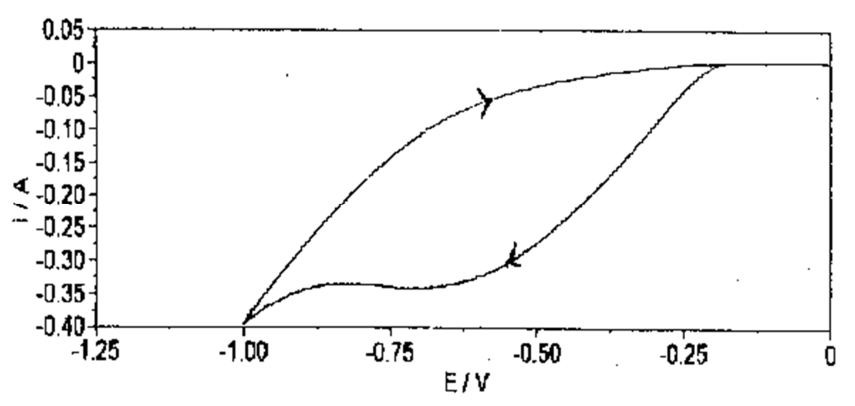

Fig 2. Cyclic Voltammogram of $6 \mathrm{M} \mathrm{HCl:} 0.5 \mathrm{~mm}$ dia Pt wire working electrode, $2 \mathrm{~mm}$ dia Pt rod counter electrode

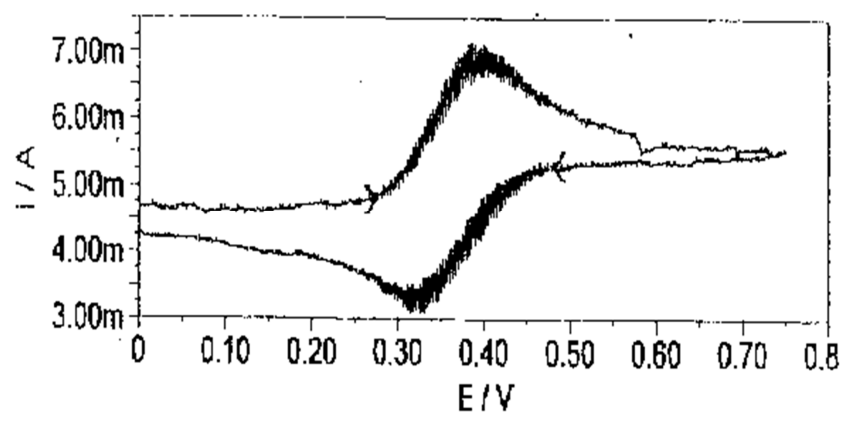

Fig 3. Cyclic voltammogram of $0.08 \mathrm{M} \mathrm{CuCl:} 0.5 \mathrm{~mm}$ dia Pt wire working electrode, $2 \mathrm{~mm}$ dia Pt rod counter electrode

One anodic peak $\mathrm{Ea}_{1}\left(\mathrm{Cu}^{1+}\right.$ to $\left.\mathrm{Cu}^{2+}\right)$ at $0.400 \mathrm{~V}$ and one cathodic peak $\mathrm{Ec}_{1}\left(\mathrm{Cu}^{2+}\right.$ to $\left.\mathrm{Cu}^{1+}\right)$ at $0.325 \mathrm{~V}$ was observed. During the $\mathrm{CuCl}-\mathrm{HCl}$ electrolysis since the cell voltage observed was less than $1 \mathrm{~V}$, practically no chlorine evolution was observed in the anolyte $(\mathrm{CuCl})$ compartment. Only cupric chloride is formed due to the oxidation of $\mathrm{CuCl}$ in the anolyte.

The formed cupric chloride is chemically completely reduced back to cuprous chloride by treatment with $10 \%$ excess stoichiometric amount of copper powder in presence of $6 \mathrm{M} \mathrm{HCl}$ at $70^{\circ} \mathrm{C}$ under stirring for $30 \mathrm{~min}$. The regenerated $\mathrm{CuCl}$ is again used in the $\mathrm{CuCl}-\mathrm{HCl}$ electrolysis.

Since platinum is a very costly metal, experiments were carried with cathodes of graphite and Pt metal coated $(0.30$ $\mathrm{mg} \mathrm{cm}$ ) graphite for the potential measurements of hydrogen liberation from $6 \mathrm{M} \mathrm{HCl}$ solution. The potential was $-0.78 \mathrm{~V}$ for plain graphite electrode, $-0.39 \mathrm{~V}$ for the Pt coated graphite electrode and $-0.18 \mathrm{~V}$ for $\mathrm{Pt}$ electrode. Considering the economic cost factor of Pt metal, Pt coated graphite electrode was subsequently used for all applied work since the rise in potential for the hydrogen liberation potential was only about $0.20 \mathrm{~V}$ and the stability of $\mathrm{Pt}$ coated graphite was found to be very high in the $\mathrm{CuCl}-\mathrm{HCl}$ electrolysis upto a duration of $50 \mathrm{~h}$.

\subsection{Applied Studies of CuCl-HCl Electrolysis}

The galvanostatic $\mathrm{CuCl}-\mathrm{HCl}$ electrolytic studies conducted is shown in Fig 1. During the electrolysis a cell voltage of $2.00 \mathrm{~V}$ was observed at room temperature. Hence various investigations were carried out with the sole aim of decreasing the cell voltage/energy.

The various parameters like temperature, anolyte concentration, catholyte concentration, cathodic current density and Pt coated graphite cathode play very crucial role in the $\mathrm{CuCl}-\mathrm{HCl}$ electrolysis for generating hydrogen gas from catholyte and cupric chloride from anolyte with minimum electrode potential/energy. In order to achieve minimum cell voltage, the above parameters were investigated on $\mathrm{CuCl}-\mathrm{HCl}$ electrolysis and the results are discussed below.

\subsection{Effect of Temperature}

High temperature electrolysis is more efficient economically than traditional room-temperature electrolysis because some of the energy is supplied as heat, which is cheaper than electricity, and also because the electrolysis reaction is more efficient at higher temperatures. At higher temperature, the particles have more kinetic energy. They move more rapidly through the solution, they collide more often and more vigorously, so the chance of a reaction increases. The time taken for a certain amount of collisions to occur decreases, so the overall time for the reaction to occur would also decrease. As given in [18] high temperature electrolysis reduces the cell voltage.

The effect of temperature with a range from $30^{\circ} \mathrm{C}$ to $85^{\circ} \mathrm{C}$ was investigated on the $\mathrm{CuCl}-\mathrm{HCl}$ electrolysis for the formation of cupric chloride and the generation of hydrogen gas. The cell voltage decreases with increase of temperature and after $70^{\circ} \mathrm{C}$ the decrease is only marginal and hence $70^{\circ} \mathrm{C}$ is fixed as optimum temperature for the specified conditions. 


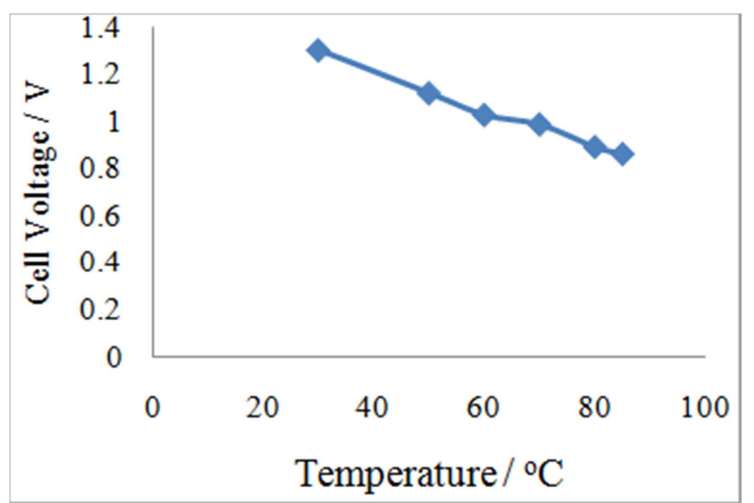

Fig 4. Effect of temperature on $\mathrm{CuCl}$ - $\mathrm{HCl}$ electrolysis with $1 \mathrm{M} \mathrm{CuCl}+6 \mathrm{M}$ $\mathrm{HCl}$ anolyte, 6M HCl catholyte, $250 \mathrm{~A} \mathrm{~m}^{-2} \mathrm{CCD} ; 5 \mathrm{~h}, 0.30 \mathrm{mg} \mathrm{cm}^{-2}$ Pt coated graphite cathode

The result of this investigation is presented in Fig 4 shown above. In this study the diffusion of copper from the anolyte into catholyte was found to be only $0.30 \mathrm{~g} \mathrm{l}^{-1}$ of copper. Platinum coated graphite was employed as cathode material and graphite plate as anode. In all these experiments the hydrogen gas liberation efficiency was found to be $\sim 100 \%$. Eventhough further increase in temperature decreased the cell voltage marginally, due to operational difficulties experiments could not be carried out at temperature greater than $70^{\circ} \mathrm{C}$.

\subsection{Effect of Anolyte Concentration}

With the aim of reducing the anode potential on the oxidation of $\mathrm{Cu}^{1+}$ into $\mathrm{Cu}^{2+}$ at the graphite anode the $\mathrm{CuCl}$ $\mathrm{HCl}$ electrolysis was carried out with varying cuprous

$$
\left.\mathrm{CuCl}_{4}{ }^{3-} \text { (or } \mathrm{CuCl}_{3}{ }^{2-} \text { if the concentration of } \mathrm{HCl}>5 \mathrm{M}\right) \rightarrow \mathrm{CuCl}_{2}+2 \mathrm{Cl}^{-}+\mathrm{e}^{-}
$$

This reaction could occur if the free chloride $(\mathrm{HCl})$ ion concentration is above $4 \mathrm{M}$. The reaction at the cathode is

$$
2 \mathrm{H}^{+}+2 \mathrm{e}^{-} \rightarrow \mathrm{H}_{2}
$$

Fig. 6 describes the reduction of protons to form hydrogen gas.

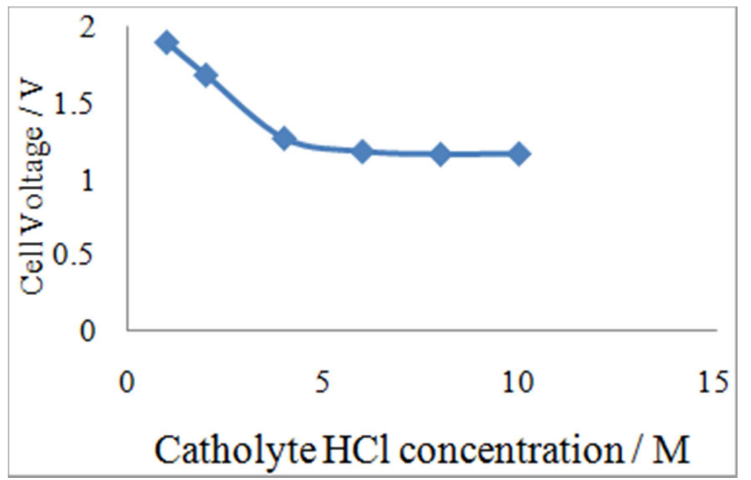

Fig 6. Effect of catholyte concentration of $\mathrm{CuCl}-\mathrm{HCl}$ electrolysis with $1 \mathrm{M}$ $\mathrm{CuCl}+6 \mathrm{M} \mathrm{HCl}$ anolyte, $500 \mathrm{~A} \mathrm{~m}^{-2} \mathrm{CCD}, 2.5 \mathrm{~A}, 2 \mathrm{~h}, \mathrm{HCl}$ catholyte

The advantage of increasing $\mathrm{HCl}$ concentration is that the amount of $\mathrm{Cu}$ diffusion into the cathode compartment could chloride concentrations (anolyte) in the range of 0.17 to $1.5 \mathrm{M}$ and it is shown in Fig 5.

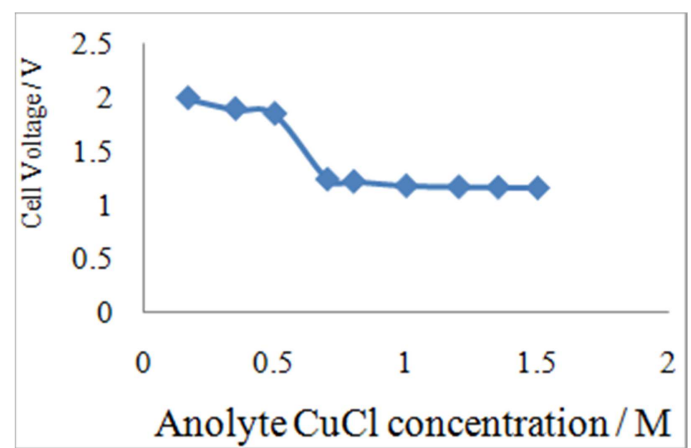

Fig 5. Effect of anolyte concentration in $\mathrm{CuCl}-\mathrm{HCl}$ electrolysis with $6 \mathrm{M} \mathrm{HCl}$

For the graphite anode the increase of cupric chloride formation with cuprous chloride concentration was obvious. At $1 \mathrm{M} \mathrm{CuCl}$ concentration the $\mathrm{CuCl}_{2}$ formation leveled off. The cell voltage was diminished by increasing the cuprous chloride concentration and after the $1 \mathrm{M}$ level the decrease in cell voltage was only meager. It is a common fact [19] that the use of high concentration of asolution is always recommended for an industrial production of its oxidized product. The studies were carried out at room temperature at a current density of $250 \mathrm{~A} \mathrm{~m}^{-2}$ in a closed divided perspex cell.

\subsection{Effect of Catholyte Concentration}

This is shown in Fig 6. In [20], the anode side of electrolysis cell, $\mathrm{Cu}^{1+}$ is oxidized to $\mathrm{Cu}^{2+}$ as

be minimized besides the reduction in the cell voltage.

For determining the optimum hydrochloric acid (catholyte) concentration, $\mathrm{CuCl}-\mathrm{HCl}$ electrolysis was carried out in the perspex divided closed cell at room temperature with $1 \mathrm{M}$ $\mathrm{CuCl}+6 \mathrm{M} \mathrm{HCl}$ anolyte with catholyte concentrations in the range of $1-10 \mathrm{M} \mathrm{HCl}$ and the result is presented in Fig 6 shown above. From the result, $6 \mathrm{M} \mathrm{HCl}$ was found to be optimum concentration. At lower $\mathrm{HCl}$ concentration $(<4 \mathrm{M})$ thin film of $\mathrm{Cu}$ over cathode surface was noticed, but at $6 \mathrm{M}$ $\mathrm{HCl}$ there was hardly a film of copper on the cathode.

\subsection{Effect of Cathodic Current Density}

The effect of cathodic current density, $\mathrm{CCD}$, in the range of $250-1000 \mathrm{~A} \mathrm{~m}^{-2}$ shown in Fig 7 was investigated at room temperature keeping the anodic current density (ACD) at 250 $\mathrm{A} \mathrm{m}^{-2}$.

The minimum CCD that could operate the electrolytic cell was found to be $250 \mathrm{~A} \mathrm{~m}^{-2}$. With rise in CCD, the cell voltage marginally increased and the $250 \mathrm{~A} \mathrm{~m}^{-2} \mathrm{CCD}$ gives the minimum cell voltage. With $0.30 \mathrm{mg} \mathrm{cm}^{-2} \mathrm{Pt}$ coated graphite cathode, the rate of proton reduction into hydrogen rose almost linearly with the CCD with the indication on the corresponding increase on cell voltage. A higher cell voltage catholyte, $250 \mathrm{~A} \mathrm{~m}^{-2} \mathrm{CCD}, 1.25 \mathrm{~A}, 2 \mathrm{~h}, \mathrm{CuCl}$ in $6 \mathrm{M} \mathrm{HCl}$ anolyte 
of $1.882 \mathrm{~V}$ was observed for the high CCD of $1000 \mathrm{~A} \mathrm{~m}^{-2}$. The $\mathrm{CCD}$ could not be increased further than $1000 \mathrm{~A} \mathrm{~m}^{-2}$ due to the onset of the copper deposit film over the platinum coated graphite cathode. Hence the optimum CCD was arrived at $250 \mathrm{~A} \mathrm{~m}^{-2}$. This result was in conformity with the chloride production from aqueous chloride solutions [21]. The observance of increased cell voltage due to increasing current density is matching with ref [18].

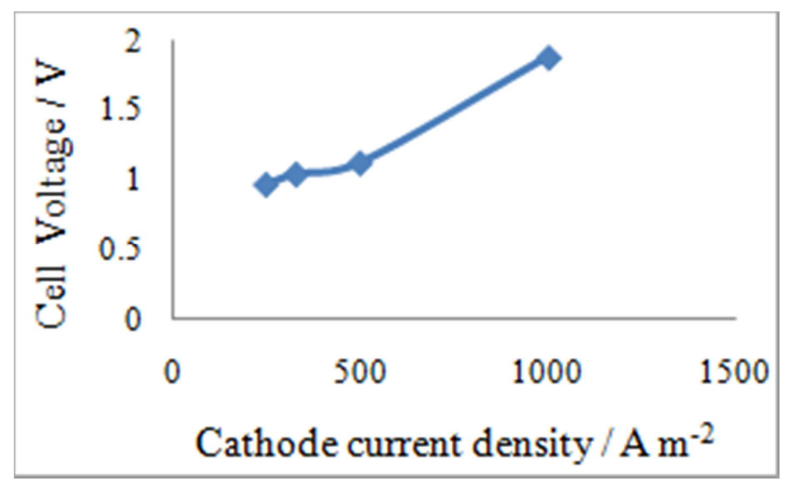

Fig 7. Effect of cathode current density on $\mathrm{CuCl}-\mathrm{HCl}$ electrolysis at $5 \mathrm{~A}, 5 \mathrm{~h}$, $1 \mathrm{M} \mathrm{CuCl+6M} \mathrm{HCl} \mathrm{anolyte,} 6 \mathrm{M} \mathrm{HCl}$ catholyte

\subsection{Effect of Platinum Coated Graphite Cathode}

The choice of electrode materials can greatly impact the electrochemical kinetics. From the literature, it is known that the reaction rate for $\mathrm{Cu}^{1+}$ oxidation is roughly three times speeder on a platinum electrode (anode) when compared to a carbon surface electrode like graphite [22]. When such electrodes surface area is increased due to coating materials over them there is a scope for some reduction in their electrode potentials.

Since plain graphite cathode gave high cathode potential, it was coated with $\mathrm{Pt}$ with varying concentrations and its optimum level was determined on the $\mathrm{CuCl}-\mathrm{HCl}$ electrolysis at $70^{\circ} \mathrm{C}$. The range of platinum concentration coated over the graphite cathode is $0.1-0.7 \mathrm{mg} \mathrm{cm}$. Fig 8 gives the experimental results obtained on this study.

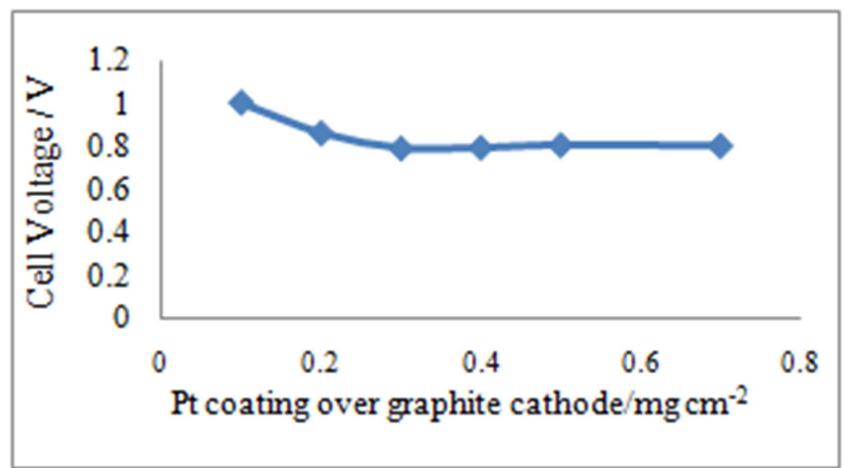

Fig 8. Effect of Platinum coating over graphite cathode in $\mathrm{CuCl}-\mathrm{HCl}$ electrolysis with $1 \mathrm{M} \mathrm{CuCl}+6 \mathrm{M} \mathrm{HCl}$ anolyte, $6 \mathrm{M} \mathrm{HCl}$ catholyte, $0.75 \mathrm{~A}, 2 \mathrm{~h}$

From the figure, it could be seen that $0.30 \mathrm{mg} \mathrm{cm}^{-2}$ coating level of platinum is found to be optimum since it gives low cell voltage and beyond this level there is hardly any appreciable reduction in cell voltage value.

\subsection{Characterization of Graphite Cathode}

The scanning electron microscopy (SEM) taken for plain graphite cathode and $0.30 \mathrm{mg} \mathrm{cm}^{-2} \mathrm{Pt}$ coated graphite cathode both before and after $\mathrm{CuCl}-\mathrm{HCl}$ electrolysis are given in Fig $9(\mathrm{a}-\mathrm{c})$.

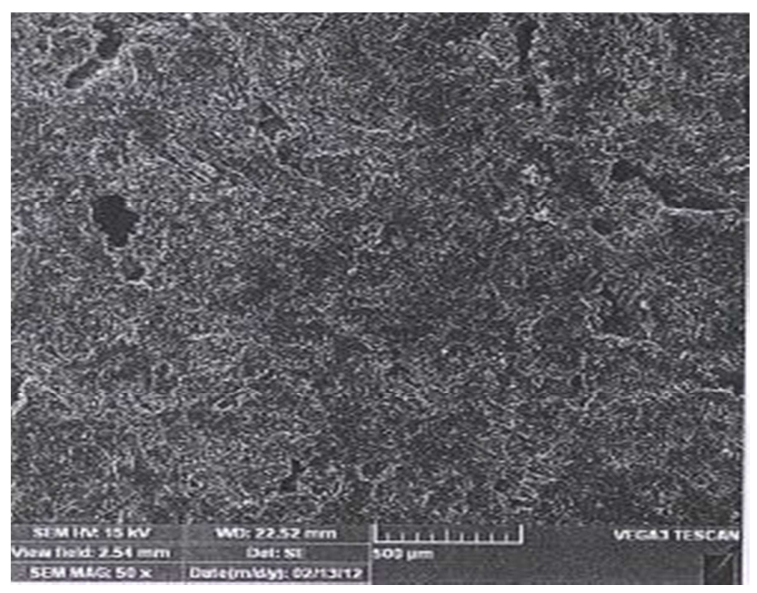

(a)

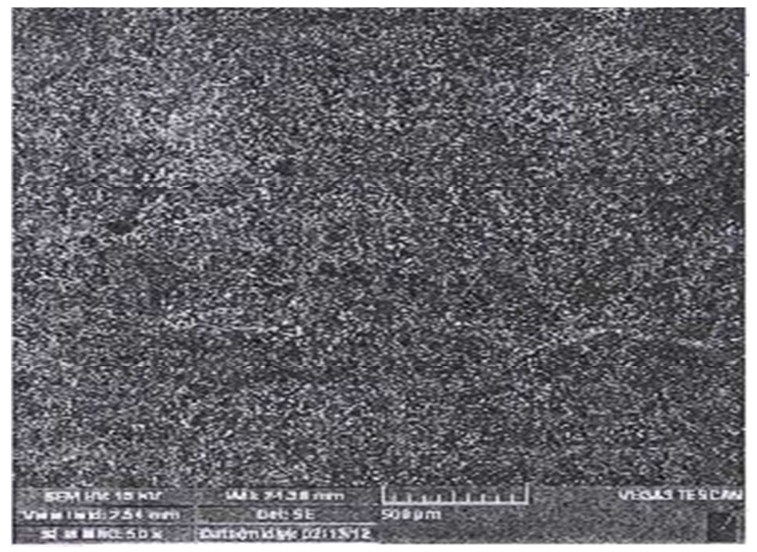

(b)

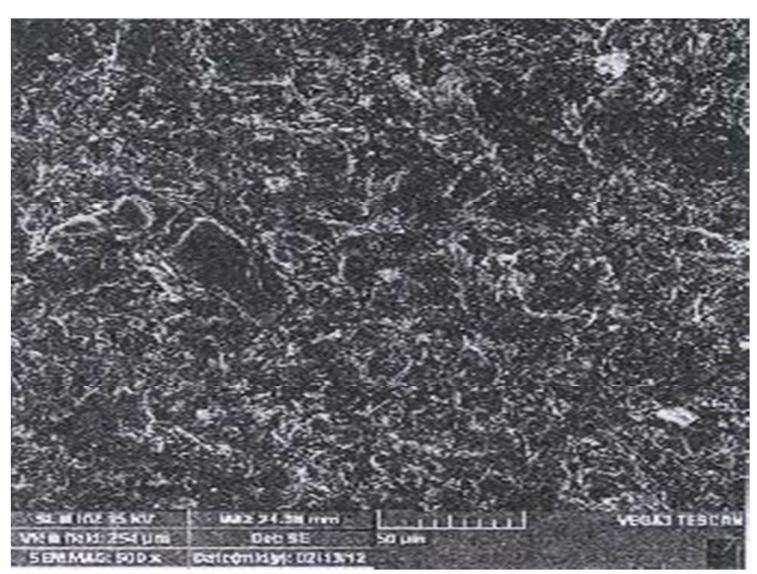

(c)

Fig 9. (a) SEM of plain graphite cathode, (b) SEM of Pt coated graphite cathode before $\mathrm{CuCl}-\mathrm{HCl}$ electrolysis, (c) SEM of Pt coated graphite cathode after $\mathrm{CuCl}-\mathrm{HCl}$ electrolysis with $5 \mathrm{~A}, 5 \mathrm{~h}, 1 \mathrm{M} \mathrm{CuCl}+6 \mathrm{M} \mathrm{HCl}$ anolyte, 6M HCl catholyte

The SEM for plain graphite cathode before electrolysis 
given in Fig 9a shows a non-uniform electrode surface having many holes while Fig $9 \mathrm{~b}$ indicates its surface gets uniform grain size when it is coated with $\mathrm{Pt}$ before electrolysis. Fig 9c presents the surface level of Pt coated graphite cathode at the end of electrolysis which does not have any hole but showing the presence of Pt even after the liberation of hydrogen gas indicating the good adherency of Pt coating over the graphite surface.

\subsection{Calculation of Voltage Efficiency}

The voltage efficiency of electrolysis is the ratio of theoretical cell voltage to the actual cell voltage. In the $\mathrm{CuCl}$ $\mathrm{HCl}$ electrolysis the current efficiency of $\mathrm{CuCl}$ into $\mathrm{CuCl}_{2}$ (anodic reaction) and $2 \mathrm{H}^{+}$into $\mathrm{H}_{2}$ (cathodic reaction) are $100 \%$. Theoretical cell voltage is: $0.230 \mathrm{~V}$ (anode potential)$(-0.240 \mathrm{~V}$ cathode potential $)=0.470 \mathrm{~V}$. The actual cell voltage is: $(0.370 \mathrm{~V})$ anode potential- $(-0.330 \mathrm{~V})$ cathode potential + $(0.100 \mathrm{~V})$ membrane drop $=0.800 \mathrm{~V}$. Hence the voltage efficiency is $0.470 \mathrm{X} 100 / 0.800$ is $58.75 \%$ which is found to be economical.

\subsubsection{Calculation of Energy Consumption}

Under the optimum conditions, the $\mathrm{CuCl}-\mathrm{HCl}$ electrolysis cell is run for $5 \mathrm{~h}$ at $5 \mathrm{~A}$ current giving an average cell voltage of $0.80 \mathrm{~V}$ liberating 10.41 of hydrogen gas $(0.928 \mathrm{~g})$ and formation of $59.3 \mathrm{~g}$ of $\mathrm{CuCl}_{2}$ (at $70^{\circ} \mathrm{C}$, normal atmosphere).

Energy consumption, EC (for hydrogen generation at cathode compartment)

$=\mathrm{CV} \times$ current $\mathrm{x}$ duration $=\mathrm{EC}$ in Watt $\mathrm{Hr}$

$=0.80 \times 5 \times 5=20 \mathrm{Watt} \mathrm{Hr}$

$=20 \times 1000=20000$ Kilo Watt $\mathrm{Hr}$ (for generating 10.41 of $\mathrm{H}_{2}$ gas ie., $0.928 \mathrm{~g}$ of $\mathrm{H}_{2}$ gas)

$=20000 / 0.928=18560$ Watt $\mathrm{Hr}$ (for generating $1.000 \mathrm{~g}$ of $\mathrm{H}_{2}$ gas) $=18560 / 1000=18.56$ Kilowatt $\mathrm{Hr} / \mathrm{Kg}$ of $\mathrm{H}_{2}$ gas

Energy consumption, EC (for cupric chloride formationat anode compartment)

$=\mathrm{CV} \times$ current $\mathrm{x}$ duration $=\mathrm{EC}$ in Watt $\mathrm{Hr}$

$=0.80 \times 5 \times 5=20 \mathrm{Watt} \mathrm{Hr}$

$=20 \times 1000=20000$ Kilo Watt $\mathrm{Hr}$ (for the formation of $59.3 \mathrm{~g}$ of $\mathrm{CuCl}_{2}$ )

$=20000 / 59.3=337.2$ Watt $\mathrm{Hr}$ (for forming $1.000 \mathrm{~g}$ of $\mathrm{CuCl}_{2}$ )

$=337.2 / 1000=0.337$ Kilowatt $\mathrm{Hr} / \mathrm{Kg}$ of $\mathrm{CuCl}_{2}$

The energy consumption values of hydrogen gas generation and $\mathrm{CuCl}_{2}$ formation are found to be very less leading to more energy savings.

\section{Conclusions}

The combustion of fossil fuels like diesel, petrol emits dangerous greenhouse gases leading to various detrimental effect on soil, water and air besides warming the globe. In this research study in order to avoid the above consequences hydrogen gas was generated through electrolysis of $\mathrm{CuCl}$ $\mathrm{HCl}$ in a nafion cation exchange membrane-324 divided closed cell made of polyethylene material for withstanding high temperature of $70^{\circ} \mathrm{C}$ at normal atmospheric pressure based on $\mathrm{Cu}-\mathrm{Cl}$ thermochemical cycle with plain graphite anode and $0.30 \mathrm{mg} \mathrm{cm}^{-2}$ platinum coated graphite cathode. During the electrolysis $6 \mathrm{M} \mathrm{HCl}$ was employed as catholyte while $1 \mathrm{M} \mathrm{CuCl}$ having $6 \mathrm{M} \mathrm{HCl}$ was used as anolyte with the anolyte circulation at $40 \mathrm{I} \mathrm{h}^{-1}$ and catholyte circulation at $10 \mathrm{l}$ $\mathrm{h}^{-1}$. The electrolysis was carried out at $250 \mathrm{~A} \mathrm{~m}^{-2}$ cathode current density having tygon tubes for bath careers for a duration of $5 \mathrm{~h}$. Cuprous chloride is oxidized to cupric chloride with $100 \%$ current efficiency and hydrogen gas was generated with $100 \%$ current efficiency with high purity at the rate of $21 \mathrm{~h}^{-1}$ in the specified cell conditions. This study has demonstrated that hydrogen gas could be generated with minimum energy having the average cell voltage of $0.78 \mathrm{~V}$. The voltage efficiency and energy consumption values of this electrolysis are found to be more promising since the $\mathrm{CuCl}$ $\mathrm{HCl}$ electrolysis can be operated with less energy for the production of hydrogen gas.

\section{Acknowledgements}

The authors express their sincere thanks to the Director, CSIR-Central Electro-Chemical Research Institute, Karaikudi-630006 and Director General-ONGC Energy Centre, Navi Mumbai-410221 for their kind permission to publish this paper, Dr. J. Prabhakar Rethinaraj, retired Scientist of EHM Division, CECRI, Karaikudi-630006 for his valuable discussions with critical suggestions, Head-TRU, ONGC Energy Centre, Navi Mumbai-410221 for the help during the project execution. The authors thank ONGC Energy Centre, Navi Mumbai-410221 for sponsoring this research project under financial assistance from CHT/OIDB.

\section{References}

[1] C.H.Dharmaraj and S.Adish Kumar, "Economical Hydrogen Production by Electrolysis using Nano Pulsed DC", International Journal of Energy and Environment, vol.3, no.1, pp. 129-136, 2012.

[2] Romdhane Ben Slama, "Production of Hydrogen by Electrolysis of Water: Effects of the Electrolyte Type on the Electrolysis Performances", Computational Water, Energy and Environmental Engineering, vol.2, pp. 54-58, 2013.

[3] B.Robert Dopp, "Hydrogen Generation via Water Electrolysis using Highly Efficient Nano metal Electrodes", Dopp Stein Enterprises. Inc., 1925 Fields Pond Glen, Marietta, GA, 30068, pp. 1-11, 2007.

[4] H.K.Abdel-Aal, K.M.Zohdy and M.Abdel Kareem,"Hydrogen Production Using Sea Water Electrolysis", The Open Fuel Cell Journal, vol.3, pp. 1-7, 2010.

[5] Nobuko Hanada, Satoshi Hino, Takayuki Ichikawa, Hiroshi Suzuki, Kenichi Takai and Yoshitsugu Kojima, "Hydrogen Generation by Electrolysis of Liquid Ammonia", Supplementary Material (ESI) for Journal of Chemical Communication of The Royal Society of Chemistry, vol.46, 2010. [DOI: $10.1039 / \mathrm{c} 0 \mathrm{cc} 01982 \mathrm{~h}]$. 
[6] Sanjay Kumar Singh and Qiang Xu, "Nano catalysts for Hydrogen Generation from Hydrazine", Catalysis Science and Technology,vol.3, pp. 1889-1900, 2013.

[7] M.A.Suarez-Gonzalez, A.M.Blanco-Marigorta and J.A.PenaQuintana, "Review on Hydrogen Production Technologies from Solar Energy", International Conference on Renewable Energies and Power Quality (ICREPQ'11), European Association for the Development of Renewable Energies, Environment and Power Quality (EA4EPQ), Las Palmas de Gran Canaria (Spain), $13^{\text {th }}$ to $15^{\text {th }}$ April, 2011.

[8] Nida Chaudhary, O.Ngadi Michael, K.Benjamin Simpson and S.Lamin Kassama, "Biosynthesis of Ethanol and Hydrogen by Glycerol Fermentation Using Escherichia Coli", Advances in Chemical Engineering and Science, vol.1, pp.83-89, 2011 [DOI: 10.4236/aces.2011.13014].

[9] Guido Collod, "Hydrogen Production via Stream Reforming with $\mathrm{CO}_{2}$ Capture", Chemical Engineering Transactions, vol.19, pp. 37-42, 2010 [DOI: 10.3303/CET 1019007].

[10] A.Rene Rozendal, V.M.Hubertus Hamelers, J.W.Gerrit Euverink, J.Sybrand Metz and J.N.Cees Buisaman, "Principle and perspective of hydrogen production through biocatalyzed electrolysis," International Journal of Hydrogen Energy, vol.31, pp. 1632-1640, 2006 [DOI: 10.1016/j.ijhydene.2005.12.006].

[11] R.H.Carty, M.M.Mazumder, J.D. Schreider and J.B. Panborn, "Thermochemical Hydrogen Production", Gas Research Institute for the Institute of Gas Technology, GRI-80/0023, Chicago, IL 60616, pp.1-4, 1981.

[12] K.F.Knoche, P.Schuster and T.Ritterbex, "Thermochemical Production of Hydrogen by a Vanadium-Chlorine Cycle.II Experimental Investigation of the Individual Reactions", International Journal of Hydrogen Energy, vol.9, no.6, pp. 473-482, 1984 [DOI: 10.1016/0360-3199(84) 90099-5].

[13] Y.Shindo,N.Ito,K.Haraya,T.Hakuta and H.Yoshitome, "Thermal Efficiency of the Magnesium-Iodine Cycle for Thermochemical Hydrogen Production", International Journal of Hydrogen Energy, vol.8, no.7, pp. 509-513, 1983 [DOI: 10.1016/0360-3199 (83) 90003-4].

[14] R.H.Elder, G.H.Priestman, B.C.Ewan and R.W.K.Allen, "The Separation of Hi X in the Sulphur-Iodine Thermochemical Cycle for Sustainable Hydrogen Production", Journal of Process Safety and Environmental Protection, vol.83, no.4, pp. 343-350, 2005 [DOI: 10.1205/psep.0434].
[15] N.Victor Balashov, S.Rich Schatz, Elena Chalkova, N.Nikolay Akinfiev, V.Mark Fedkin and N.Serguei Lvov, "CuCl Electrolysis for Hydrogen Production in the $\mathrm{Cu}-\mathrm{Cl}$ Thermochemical Cycle", Journal of The Electrochemical Society, vol.158, no.3, pp. B266-B275, 2011.

[16] A.Michele Lewis and G.Joseph Masin, "The Evaluation of Alternative Thermochemical Cycles - Part II: The DownSelection Process", International Journal of Hydrogen Energy, vol.xxx, pp. 1-11, 2008 (article in press) [DOI: 10.1016/j.ijhydene.2008.07.085].

[17] G.Naterer, S.Suppiah, M.Lewis, K.Gabriel, I.Dincer, M.A.Rosen, M.Fowler, G.Rizvi, E.B.Easton, B.M.Ikeda, M.H.Kaye, L.Lu, I.Pioro, P.Spekkens, P.Tremaine, J.Mostaghimi, J.Avsec and J.Jiang, "Recent Canadian Advances in Nuclear-based Hydrogen Production and the Thermochemical $\mathrm{Cu}-\mathrm{Cl}$ Cycle", International Journal of Hydrogen Energy, vol.34, pp. 2901-2917, 2009.

[18] F.Mohammadi, S.N.A.Ashrafizadeh and A.Sattari, "Aqueous $\mathrm{HCl}$ Electrolysis Utilizing an Oxygen Reducing Cathode", Chemical Engineering Journal,vol.155, pp. 757-762, 2009.

[19] M.A.Aziz, M.S.Ali and M.M.Islam, "Effect of solution concentration on oxidization", Chemical Engineering and Research Bulletin, vol.10, pp. 762-763, 1980.

[20] G.Naterer, S.Suppiah, L.Stolberg, M.Lewis, Z.Wang, V.Daggupati, K.Gabriel, I.Dincer, M.A.Rosen, P.Spekkens, S.N.Lvov, M.Fowler, P.Tremaine, J.Mostaghimi, E.B.Easton, L.Travani, G.Rizvi, B.M.Ikeda, M.H.Kaye, L.Lu, I.Pioro, W.R.Smith, E.Secnik, J.Jiang and J.Avsec, "Recent Canadian Advances in Nuclear-based Hydrogen Production and the Thermochemical $\mathrm{Cu}-\mathrm{Cl}$ Cycle", International Journal of Hydrogen Energy, vol.35, pp. 10905-10926, 2010.

[21] A.Khelifa, S.Moulay, F.Hannane, S.Benslimene and M.Hecini, "Application of an Experimental Design Method to Study the Performance of Electrochlorination Cells", Desalination, vol.160, pp. 91-98, 2004.

[22] R.Santhanam and G.Easton, "Novel Ceramic Carbon Electrode (CCE) Materials for $\mathrm{CuCl}$ Electrolysis", ORF Workshop on Nuclear-Based Thermochemical Hydrogen Production, Chalk River, ON, Canada, E.B, 2008 (Unpublished Report). 